\title{
A Comparative Study of Dexmedetomidine and Clonidine for Attenuation of Hemodynamic Response during Laryngoscopy and Intubation
}

\author{
Sanjay Kumar Gupta ${ }^{\circledR 1}$, Saurabh Singhal ${ }^{\odot 2}$ \\ ${ }^{1}$ Assistant Professor, Department of Anesthaesia, F. H. Medical College, Agra, Utter Pradesh, India, ${ }^{2}$ Associate Professor, Department of Anesthaesia, F. H. Medical \\ College, Agra, Utter Pradesh, India.
}

\section{Abstract}

Background: The present study was conducted to compare dexmedetomidine and clonidine for attenuation of hemodynamic response during laryngoscopy and intubation. Subjects and Methods: Group I patients received $0.9 \%$ normal saline (placebo), group II patients received 0.5 $\mu \mathrm{g} / \mathrm{kg}$ of dexmedetomidine and group III patients received $3 \mu \mathrm{g} / \mathrm{kg}$ of or clonidine. Each group had 15 patients. Results: The mean age in group I was 28.2 years, in group II was 32.1 years and in group III was 33.2 years, mean weight was 61.2 years, in group II was 60.4 years and in group III was 62.1 years, height was $156.2 \mathrm{~cm}$, in group II was $157.1 \mathrm{~cm}$ and in group III was $152.8 \mathrm{~cm}$. There were 8 males and 7 females in group I, 6 males and 9 females in group II and 7 males and 8 females in group III. The mean SBP (mm Hg) in group I was 121.4 and in group II was 122.6 , and in group III was 127.4, DBP (mm Hg) was 76.2 in group I, 78.4 in group II and 78.2 in group III. MAP (mm $\mathrm{Hg}$ ) was 86.7 in group I, 93.2 in group II and 92.5 in group III. HR (bpm) was 74.2 in group I, 78.4 in group II and 77.3 in group III. \% oxygen saturation was 98.2 in group I, 98.5 in group II and 97.9 in group III. The difference was non- significant $(\mathrm{P}>0.05)$. Conclusion: Authors found that both groups were equally effective in causing attenuation of hemodynamic response to endotracheal intubation.

Keywords: Clonidine, Endotracheal intubation, hemodynamic

Corresponding Author: Saurabh Singhal, Associate Professor, Department of Anesthaesia, F. H. Medical College, Agra, Utter Pradesh, India. E-mail: dr_saurabhsinghal25@yahoo.co.in

Received: 16 June 2020

Revised: 21 July 2020

Accepted: 28 July 2020

Published: 16 December 2020

\section{Introduction}

Tachycardia and hypertension are exaggerated cardiovascular reflexes activated by stimuli such as endotracheal intubation and laryngoscopy due to sympathetic nervous system stimulation. ${ }^{[1]}$ The aim of any anesthesia is to control these reflexes. Patients with history of cardiovascular and cerebrovascular diseases are more prone to have these reflexes. ${ }^{[2]}$

Numerous researchers have tried various drugs for hinder the stress response to endotracheal intubation and laryngoscopy. An ideal drug should be capable of inducing analgesia, sedation and reducing anaesthetic drug requirement. ${ }^{[3]}$ Among all, $\alpha-2$ agonists like clonidine and dexmedetomidine are two drugs shown superior effects than others. Studies mentioning that 0.5 and $1 \mu \mathrm{g} / \mathrm{kg}$ dosage of dexmedetomidine have approximately 8 times high affinity for alpha 2 receptors than clonidine. ${ }^{[4]}$ In this dose dexmedetomidine shows effective attenuation of stress response to laryngoscopy and endotracheal intubation as compared to cloni- dine as reported by numerous authors. The secretion of norepinephrine decreases significantly leading to diminished sympathetic activity. Patients experience hypotension and decreased heart rate (bradycardia) especially with dosage of $1 \mu \mathrm{g} / \mathrm{kg}$ body weight. ${ }^{[5]}$

It is observed that premedication with clonidine blunts the stress response to surgical stimuli and subsequently reduces and anaesthetic and narcotic drug requirement. Moreover, clonidine increases the cardiac baroreceptor reflex sensitivity to increase systolic blood pressure and hence stabilizes blood pressure. ${ }^{[6]}$ The present study was conducted to compare dexmedetomidine and clonidine for attenuation of hemodynamic response during laryngoscopy and intubation.

\section{Subjects and Methods}

This study was conducted among 45 adult patients of both genders of American Society of Anesthesiologists (ASA) physical status I and II. All patients were informed regarding 
the study and their written consent was also obtained. Ethical committee of institute approved the study.

Patients were randomly divided into 3 groups of 15 each. Group I patients received $0.9 \%$ normal saline (placebo), group II patients received $0.5 \mu \mathrm{g} / \mathrm{kg}$ of dexmedetomidine and group III patients received $3 \mu \mathrm{g} / \mathrm{kg}$ of or clonidine.

Parameters such as heart rate, systolic blood pressure (SBP), diastolic blood pressure (DBP) and mean arterial pressure (MAP) were recorded at T0-before drug administration, T1-After drug administration, T2-After induction, T3-After intubation and at $\mathrm{T} 4$ to $\mathrm{T} 6-2,4,6,8$ and 10 min after intubation respectively. Results of the study were statistically analyzed using appropriate tests with level of significance set below 0.05 .

\section{Results}

\begin{tabular}{llll}
\hline Table 1: Distribution of patients & & \\
\hline Groups & Group I & Group II & Group III \\
Drug & $\begin{array}{l}\text { Normal } \\
\text { saline }\end{array}$ & Dexmedeton & Clonidine \\
Number & 15 & 15 & 15 \\
\hline
\end{tabular}

[Table 1] shows that each group had 15 patients.

[Table 2] shows that mean age in group I was 28.2 years, in group II was 32.1 years and in group III was 33.2 years, mean weight was 61.2 years, in group II was 60.4 years and in group III was 62.1 years, height was $156.2 \mathrm{~cm}$, in group II was 157.1 $\mathrm{cm}$ and in group III was $152.8 \mathrm{~cm}$. There were 8 males and 7 females in group I, 6 males and 9 females in group II and 7 males and 8 females in group III. The difference was nonsignificant $(\mathrm{P}>0.05)$.

[Table 3, Figure 1] shows that mean SBP $(\mathrm{mm} \mathrm{Hg})$ in group I was 121.4 and in group II was 122.6, and in group III was 127.4, DBP ( $\mathrm{mm} \mathrm{Hg}$ ) was 76.2 in group I, 78.4 in group II and 78.2 in group III. MAP ( $\mathrm{mm} \mathrm{Hg}$ ) was 86.7 in group I, 93.2 in group II and 92.5 in group III. HR (bpm) was 74.2 in group I, 78.4 in group II and 77.3 in group III. \% oxygen saturation was 98.2 in group I, 98.5 in group II and 97.9 in group III. The difference was non- significant $(\mathrm{P}>0.05)$.

\section{Discussion}

It is evident that clonidine bring about bradycardia, hypotension, reduction in systemic vascular resistance (SVR) and cardiac output. ${ }^{[7]}$ It is considered to be a potent antihypertensive drug. Clonidine also prohibits vasopressin and catecholamines secreation and modulates the hemodynamic changes induced by laryngoscopy and in pneumoperitoneum. It has been found effective in patients with cataract, in neurosurgical patients

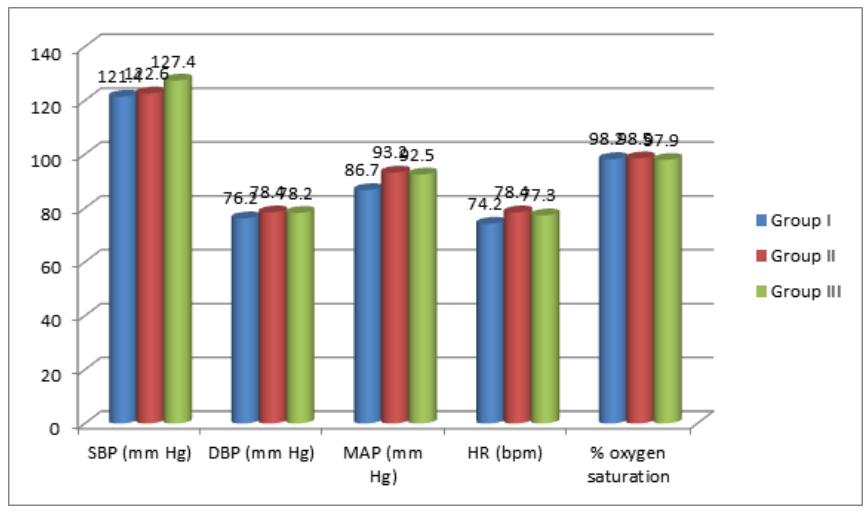

Figure 1: Comparison of parameters

and patients requiring orthopedic procedures. ${ }^{[8]}$ Data about sedation and dexmedetomidine, metabolic rate and ventilation, oxygen saturation level in dexmedetomidine-premedicated patients and postoperative sympatholytic effects is present in literature. Dexmedetomidine has additional advantage of having anxiolytic and sedative property making it popular among Anesthesiologists. ${ }^{[9]}$ The present study was conducted to compare dexmedetomidine and clonidine for attenuation of hemodynamic response during laryngoscopy and intubation.

In present study we distributed 45 patients in group of 15 . Group I patients received $0.9 \%$ normal saline (placebo), group II patients received $0.5 \mu \mathrm{g} / \mathrm{kg}$ of dexmedetomidine and group III patients received $3 \mu \mathrm{g} / \mathrm{kg}$ of or clonidine. Pooja et al, ${ }^{[10]}$ in their study group 1 received $2 \mu \mathrm{g} / \mathrm{kg}$ of clonidine and group 2 patients received $1 \mu \mathrm{g} / \mathrm{kg}$ of dexmedetomidine Results showed that the mean scores of SBP were higher in group 1 among both the groups over the periods. The mean scores of DBP in both groups was similar over the periods with slightly being higher in Group 1 especially after $30 \mathrm{~min}$ to till end as compared to Group 2.

We found that the mean age in group I was 28.2 years, in group II was 32.1 years and in group III was 33.2 years, mean weight was 61.2 years, in group II was 60.4 years and in group III was 62.1 years, height was $156.2 \mathrm{~cm}$, in group II was $157.1 \mathrm{~cm}$ and in group III was $152.8 \mathrm{~cm}$. There were 8 males and 7 females in group I, 6 males and 9 females in group II and 7 males and 8 females in group III.

Sarkar et al, ${ }^{[11]}$ compared the effect of intravenous (IV) infusion of dexmedetomidine and clonidine and classified patients into Group P, Group D and Group C of 25 patients each. The mean systolic blood pressure in Group D and Group C were significantly lower $(<0.01)$ than group P. As compared to Group P, the mean arterial pressure in Group D was significantly higher at after infusion and after induction intervals but significantly lower after intubation and subsequent intervals. However, in Group $\mathrm{C}$, the mean 
Table 2: Demographic characteristics

\begin{tabular}{lllll}
\hline Parameters & Group I & Group II & Group III & P-value \\
Age (years) & 28.2 & 32.1 & 33.2 & 0.95 \\
Weight $(\mathrm{Kg})$ & 61.2 & 60.4 & 62.1 & 0.84 \\
Height $(\mathrm{cm})$ & 156.2 & 157.1 & 152.8 & 0.91 \\
M: F & $8: 7$ & $6: 9$ & $7: 8$ & 0.92 \\
\hline
\end{tabular}

Table 3: Comparison of parameters

\begin{tabular}{lllll}
\hline Parameters & Group I & Group II & Group III & P value \\
SBP $(\mathrm{mm} \mathrm{Hg})$ & 121.4 & 122.6 & 127.4 & 0.15 \\
\hline DBP $(\mathrm{mm} \mathrm{Hg})$ & 76.2 & 78.4 & 78.2 & 0.19 \\
MAP (mm Hg) & 86.7 & 93.2 & 92.5 & 0.35 \\
\hline HR (bpm) & 74.2 & 78.4 & 77.3 & 0.21 \\
\hline \% oxygen saturation & 98.2 & 98.5 & 97.9 & 0.11 \\
\hline
\end{tabular}

value was significantly lower as compared to Group $\mathrm{P}$ at all-time intervals except after infusion and after induction intervals. As compared to Group P, the mean HR in Group $\mathrm{D}$ was significantly higher at after infusion and after induction intervals. However at all the subsequent intervals, Group D was significantly lower as compared to Group P.

We observed that the mean SBP ( $\mathrm{mm} \mathrm{Hg}$ ) in group I was 121.4 and in group II was 122.6, and in group III was 127.4, DBP $(\mathrm{mm} \mathrm{Hg})$ was 76.2 in group I, 78.4 in group II and 78.2 in group III. MAP (mm Hg) was 86.7 in group I, 93.2 in group II and 92.5 in group III. HR (bpm) was 74.2 in group I, 78.4 in group II and 77.3 in group III. \% oxygen saturation was 98.2 in group I, 98.5 in group II and 97.9 in group III. The difference was non- significant $(\mathrm{P}>0.05)$.

Sebastian et al, ${ }^{[12]}$ in their study divided patients into group A received normal saline, group $\mathrm{B}$ received injection dexmedetomidine $0.5 \mu \mathrm{g} / \mathrm{kg}$ and group $\mathrm{C}$ received injection dexmedetomidine $0.75 \mu \mathrm{g} / \mathrm{kg}$ as infusion over $10 \mathrm{~min}$. A statistically significant difference was found between dexmedetomidine and normal saline in heart rate, systolic, diastolic and mean arterial pressures at all time points after tracheal intubation with dexmedetomidine $0.75 \mu \mathrm{g} / \mathrm{kg}$ dose was most effective. Sedation scores were more with dexmedetomidine. Taittonen et al, ${ }^{[13]}$ observed similar response patterns when while compared clonidine, placebo and attributed and dexmedetomidine and suggested that this is the distinguishing feature of $\alpha 2-$ agonists, including clonidine and dexmedetomidine.

The limitation of the study is small sample size.

\section{Conclusion}

Authors found that both groups were equally effective in causing attenuation of hemodynamic response to endotracheal intubation.

\section{References}

1. Coursin DB, Coursin DB, Maccioli GA. Dexmedetomidine. Curr Opin Crit Care. 2001;7(4):221-226. Available from: https://dx.doi.org/10.1097/00075198-200108000-00002.

2. Matot I, Sichel JY, Yofe V, Gozal Y. The Effect of Clonidine Premedication on Hemodynamic Responses to Microlaryngoscopy and Rigid Bronchoscopy. Anesth Analg. 2000;91(4):828-833. Available from: https://dx.doi.org/10. 1097/00000539-200010000-00011.

3. Taittonen MT, Kirvelä OA, Aantaa R, Kanto JH. Effect of clonidine and dexmedetomidine premedication on perioperative oxygen consumption and haemodynamic state. $\mathrm{Br} \mathrm{J}$ Anaesth. 1997;78(4):400-406. Available from: https://dx.doi. org/10.1093/bja/78.4.400.

4. Yildiz M, Tavlan A, Tuncer S, Reisli R, Yosunkaya A, Otelcioglu S. Effect of Dexmedetomidine on Haemodynamic Responses to Laryngoscopy and Intubation. Drugs R D. 2006;7(1):43-52. Available from: https://doi.org/10.2165/ 00126839-200607010-00004.

5. Bloor BC, Ward DS, Belleville JP, Maze M. Effects of Intravenous Dexmedetomidine in Humans. Anesthesiol. 1992;77(6):1134-1142. Available from: https://dx.doi.org/10. 1097/00000542-199212000-00014.

6. Belleville JP, Ward DS, Bloor BC, Maze M. Effects of intravenous dexmedetomidine in humans. I. Sedation, ventilation, and metabolic rate. Anesthesiology. 1992;77:11251158. Available from: https://doi.org/10.1097/00000542199212000-00013.

7. Gerges FJ, Kanazi GE, Jabbour-khoury SI. Anesthesia for laparoscopy: a review. J Clin Anesth. 2006;18(1):67-78. Available from: https://dx.doi.org/10.1016/j.jclinane.2005.01. 013.

8. Singh S, Arora K. Effect of oral clonidine premedication on perioperative haemodynamic response and post-operative 
analgesic requirement for patients undergoing laparoscopic cholecystectomy. Indian J Anaesth. 2011;55(1):26-26. Available from: https://dx.doi.org/10.4103/0019-5049.76583.

9. Tripathi D, Dubey S, Raval P, Shah T, Doshi S. Hemodynamic stress response during laparoscopic cholecystectomy: Effect of two different doses of intravenous clonidine premedication. J Anaesthesiol Clin Pharmacol. 2011;27(4):475-475. Available from: https://dx.doi.org/10.4103/0970-9185.86586.

10. Gautam P. Comparative Study of Clonidine Vs Dexmedetomidine for Hemodynamic Stability and Postoperative Analgesia during Laproscopic Surgery. Int J Contemp Med Res. 2019;6(1):1-7. Available from: https://dx.doi.org/10.21276/ ijcmr.2019.6.1.20.

11. Singh R, Sarkar A, Choubey S, Awasthi S, Tripathi RK. Comparison of effects of intravenous clonidine and dexmedetomidine for blunting pressor response during laryngoscopy and tracheal intubation: A randomized control study. Anesth Essays Res. 2014;8:361-361. Available from: https://dx.doi.org/10. 4103/0259-1162.143144.

12. Talikoti A, Sebastian B, Krishnamurthy D. Attenuation of haemodynamic responses to laryngoscopy and endotracheal intubation with intravenous dexmedetomidine: A comparison between two doses. Indian J Anaesth. 2017;61:48-48.
Available from: https://dx.doi.org/10.4103/0019-5049.198404. 13. Taittonen MT, Kirvelä OA, Aantaa R, Kanto JH. Effect of clonidine and dexmedetomidine premedication on perioperative oxygen consumption and haemodynamic state. British Journal of Anaesthesia. 1997;78(4):400-406. Available from: https://dx.doi.org/10.1093/bja/78.4.400. doi:10.1093/bja/78.4.400.

Copyright: (C) the author(s), 2020. It is an open-access article distributed under the terms of the Creative Commons Attribution License (CC BY 4.0), which permits authors to retain ownership of the copyright for their content, and allow anyone to download, reuse, reprint, modify, distribute and/or copy the content as long as the original authors and source are cited.

How to cite this article: Gupta SK, Singhal S. A Comparative Study of Dexmedetomidine and Clonidine for Attenuation of Hemodynamic Response during Laryngoscopy and Intubation. Acad. Anesthesiol. Int. 2020;5(2):49-52.

DOI: dx.doi.org/10.21276/aan.2020.5.2.10

Source of Support: Nil, Conflict of Interest: None declared. 